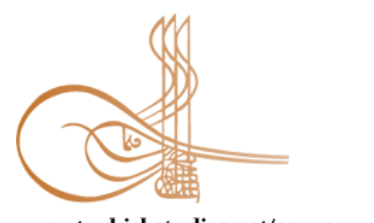

www.turkishstudies.net/economy
Turkish Studies - Economics, Finance, Politics

eISSN: 2667-5625

Research Article / Araștırma Makalesi

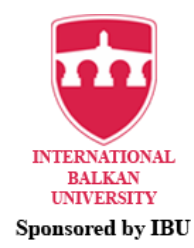

Sponsored by IBU

\title{
Bankalarda İç Denetim ve İç Kontrol Bulgularının Raporlanması ile Çözümlenmesi: Bankaların Bilgi Sistemleri ve Elektronik Bankacılık Hizmetleri Hakkında Yönetmelik Kapsamında Bir İnceleme
}

\author{
Reporting and Resolution of Internal Audit and Internal Control Findings in Banks: An \\ Examination within the Context of Regulation on Banks' Information Systems and Electronic \\ Banking Services
}

\author{
Cevdet Kız1l ${ }^{*}$ - Mustafa Tevfik Kartal ${ }^{* *}$
}

\begin{abstract}
A variety of audit operations are carried out in banks by assurance providers. Audit findings are reported to the senior management at the end of audit operations. When the width of organizational structures and branch networks of banks are taken into consideration, several audit findings with different importance levels are reported while hundreds of audit reports are issued by assurance providers per year. Therefore, supervision and monitoring of audit findings at the highest level becomes a requirement in banks. The regulation published on 15.03.2020 introduces new rules regarding audit findings in banks. This study is prepared to evaluate the possible effects of mentioned regulation in terms of audit findings, audit reporting and audit processes. Also, critical points in reporting and completion of audit findings by banks are emphasized in the study. According to the results of the research, the audit findings resulting from the assurance activities performed by the internal control and internal audit should be reported on a consolidated basis through a finding monitoring system, should be observed by the senior management of the bank, and these activities should be continued for all audit findings, not just the information system findings. In addition, it is recommended to evaluate the transition period until 01.07 .2020 by banks, to establish consolidated findings tracking systems that will cover all findings at banks and the Banking Regulation and Supervision Agency (BRSA), and to take additional measures when necessary. However, the relevant regulation will provide various benefits and contributions from the perspective of reporting, analyzing and handling the audit findings more carefully by the senior management. Still, the regulation is incomplete as it focuses only on information technology findings and should be extended to cover all audit findings.
\end{abstract}

Structured Abstract: Accounting is a science, which is related with recording, categorizing, summarizing, reporting, analyzing and interpreting monetary transactions. Considering the early stages and invention of

\footnotetext{
${ }^{*}$ Doç.Dr., İstanbul Medeniyet Üniversitesi, Siyasal Bilgiler Fakültesi, İşletme Bölümü

Assoc. Prof. Dr., Istanbul Medeniyet University, Faculty of Politics Sciences, Department of Management

ORCID 0000-0003-0196-2386

cevdetkizil@yahoo.com

** Dr., Borsa İstanbul, Stratejik Planlama ve Yatırımcı İlişkileri Direktörlüğü

Ph.D., Borsa Istanbul, Strategic Planning and Investor Relations Directorate

ORCID 0000-0001-8038-8241

mustafatevfikkartal@gmail.com

Cite as/ Atıf: Kızıl, C. \& Kartal, M. T. (2020). Bankalarda iç denetim ve iç kontrol bulgularının raporlanması ile çözümlenmesi: Bankaların bilgi sistemleri ve elektronik bankacılık hizmetleri hakkında yönetmelik kapsamında bir inceleme. Turkish Studies - Economy, 15(3), 1485-1500. https://dx.doi.org/10.47644/TurkishStudies.43891

Received/Geliş: 31 May/Mayıs 2020

Accepted/Kabul: 20 September/Eylül 2020

Copyright $\subset$ INTAC LTD, Turkey
} 
accounting, it will be right to state that accounting was first used only as a tool of recording. However, accounting developed through years and became a modern science with Italian mathematician Luca Pacioli's Summa Arithmetica book and double-entry book keeping system. Speaking for today, accounting evolved to a completely different character which is tightly integrated with technology. Issues such as intellectual capital reporting, integrated reporting, non-financial reporting, accounting ethics, application of COBIT on the accounting system, COSO model in internal controls, cloud accounting, encryrpted auditing reports, electronic (digital) accounting and cryptocurrency accounting are widely discussed nowadays.

Accounting and auditing are closely related with each other. An efficient auditing is only possible with a strong background in accounting. Financial auditing is the process of investigating an organization's financial records to detect if they are accurate and in accordance with any applicable rules such as generally accepted accounting standards, regulations and laws. Audit types can be classified under various criteria. The most common classification is under two titles according to who conducts the audit and the benefit (audit objectives) desired at the end of the audit. Concerning audit types according to the statuses (titles) of auditors, these can be listed as internal audit, external audit (independent audit) and public audit. According to the purpose to be achieved by the audit, audit types can be explained under three headings as financial statements audit, compliance audit and activity audit.

Internal controls are practices, procedures, policies, processes, systems and actions that function to reduce risks in an organization. The internal control system, on the other hand, is a management tool, a highlevel administrative control mechanism, established for the purpose of achieving the goals and objectives throughout the organization, covering all these controls, but also including management and organization, risk assessment, communication, information systems and internal audit. The fact that internal audit activities are healthy and effective depends on the existence of a healthy and effective internal control system and internal control environment. In companies and institutions that do not have an internal control system or whose internal control structures have not been developed with a certain systematic, internal auditors experience much more difficulty to audit, and it is not possible to obtain efficiency from the audit. In companies and institutions that have established, updated and regularly reviewed the internal control system, the cause, effect, criterion elements of the findings to be revealed are more easily identifiable. Hence, it is necessary to look at the lack of internal control in institutions, not as a deficiency alone, but as a whole with other systems that it negatively affects and to take necessary measures. The reason is that, internal control reveals a positive or negative impact with a multiplier effect.

The bank is an economic institution that accepts deposits, which aims to use this deposit in various credit transactions in the most efficient way, or whose main subject of activities is to regularly take out or give credit. As another definition, the bank is an economic unit that carries out and regulates all kinds of transactions in the fields of money, credit and capital, and carries out activities to meet all kinds of needs of private or public individuals and businesses in this field. Banking activities and the banking sector is critically important for any county. The reason is that, banking sector is the locomotive of national economies.

This study analyzes the reporting and resolution of internal audit and internal control findings in banks within the scope of regulation on banks' information systems and electronic banking services. The regulation, published on 15.03.2020, introduces new rules for audit findings in banks. This research has been prepared in order to evaluate the possible effects of the related regulation in terms of audit findings, audit reporting and audit processes. In addition, critical issues that banks should pay attention in reporting and analyzing audit findings were emphasized.

In regards to research results, it is imperative that the audit findings observed as a result of assurance activities performed by internal control and internal audit are reported in a consolidated manner through a detecting monitoring system, they are supervised by the senior management of the bank, and these activities are continued for all audit findings, not only information system findings. In addition, it seems logical to evaluate the period until 01.07.2020 by banks, to build consolidated findings tracking systems by including all the findings within the scope of banks and the Banking Regulation and Supervision Agency (BRSA), and to take additional measures if necessary. However, the relevant regulation will provide benefits with various contributions from the perspective of reporting, analyzing and handling meticulously by senior management at the banks. On the other hand, regulation is far from ideal because it concentrates only on information technology findings. It would be right to design the regulation to include all audit findings.

Turkish Studies - Economy, 15(3) 
Keywords: Accounting, Bank, Audit, Reporting, Internal Audit, Internal Control

Öz: Güvence sağlayan taraflarca bankalarda çeşitli denetim çalışmaları gerçekleştirilmektedir. Denetim çalışmalarının sonunda ise denetim bulguları üst yönetimlere raporlanmaktadır. Bankaların organizasyon yapılarının ve şube ağlarının genişliği dikkate alındığında, güvence sağlayan taraflarca bir yıl içinde yüzlerce denetim raporu düzenlenirken farklı önem derecelerine sahip çok sayıda denetim bulgusu raporlanmaktadır. Dolayısıyla, bankalarda denetim bulgularının en üst düzeyde takip edilmesi bir gereklilik haline gelmektedir. 15.03.2020 tarihinde yayınlanan yönetmelik, bankalarda denetim bulgularına yönelik yeni kurallar getirmektedir. $\mathrm{Bu}$ çalışma, denetim bulguları, denetim raporlamaları ve denetim süreçleri açısından ilgili yönetmeliğin muhtemel etkilerinin değerlendirilmesine yönelik olarak hazırlanmıştır. Ayrıca, çalışmada denetim bulgularının raporlanmasında ve çözümlenmesinde bankaların dikkat etmesi gereken kritik hususlar vurgulanmıştır. Araştırma sonuçlarına göre, iç kontrol ve iç denetim tarafindan gerçekleştirilen güvence faaliyetleri neticesinde ortaya çıkan denetim bulgularının bir bulgu takip sistemi aracılığıyla konsolide bazda raporlanması, banka üst yönetimlerince gözetilmesi ve bu faaliyetlerin yalnızca bilgi sistemleri bulguları değil, tüm denetim bulguları için sürdürülmesi gerekmektedir. Bunun yanında, 01.07.2020 tarihinde kadar olan geçiş sürecinin bankalarca iyi değerlendirilmesi, bankalar ve Bankacılık Düzenleme ve Denetim Kurumu (BDDK) nezdinde tüm bulguları kapsayacak konsolide bulgu takip sistemleri kurulması, sürecin BDDK tarafından gözetilmesi ve gerektiğinde ek önlemler alınması önerilmektedir. Fakat, ilgili yönetmelik bankalarda denetim bulgularının raporlanması, çözümlenmesi ve üst yönetim tarafından daha dikkatli bir şekilde ele alınması perspektifinden çeşitli katkılar ile faydalar sağlayacaktır. Bununla birlikte, düzenleme sadece bilgi teknolojileri bulgularına odaklandığı için eksik yapılmış olup tüm denetim bulgularını kapsayacak şekilde genişletilmelidir.

Anahtar Kelimeler: Muhasebe, Banka, Denetim, Raporlama, İç Denetim, İç Kontrol

\section{Giriş}

Ülkeler ekonomik ve ticari faaliyetlerin finanse edilmesi için fon kaynağına ihtiyaç duymaktadırlar. Söz konusu ihtiyaç, bankacılık sektörü ve sermaye piyasaları olmak üzere iki temel kaynaktan sağlanmaktadır (Kartal vd., 2018a: 42). Türkiye'de ise ihtiyaç duyulan fon kaynakları büyük ölçüde bankacılık sektöründen elde edilmektedir. Bankalar, fon sağlamadaki söz konusu aracılık fonksiyonları nedeniyle finansal piyasalar içinde oldukça önemli bir rol oynamaktadırlar (Dinçer vd., 2016: 33). Dolayısıyla, Türkiye'de bankalar sistemik öneme sahip finansal kuruluşların başında yer almaktadırlar.

Bankaların finansal piyasalarda sahip olduğu önem dolayısıyla, bankacılık sektöründe yaşanan gelişmeler ülke ekonomileri üzerinde önemli etkiler oluşturmaktadır. Bu noktadan hareketle, Türk bankacılık sektörü birçok düzenlemeye tabi tutulmaktadır. $\mathrm{Bu}$ düzenlemelerin başında yürürlükte bulunan 5411 sayılı Bankacılık Kanunu (BK) yer almaktadır. Ek olarak, BK tarafından verilen yetkiye istinaden Bankacılık Düzenleme ve Denetleme Kurumu (BDDK) tarafından ikincil düzenlemeler de yapılmaktadır. Diğer taraftan, Ticaret Bakanlığı, Türkiye Cumhuriyet Merkez Bankası, Sermaye Piyasası Kurulu ve Kamu Gözetimi, Muhasebe ve Denetim Standartları Kurumu gibi düzenleyici ve denetleyici kurumlar görev ve yetki alanlarıyla sınırlı olmak üzere bankaların faaliyetlerine yönelik düzenlemeler yapmaktadır. Ayrıca, Türkiye Bankalar Birliği ve Türkiye Katılım Bankaları Birliği tarafından da bankalara yönelik yapılan düzenlemeler bulunmaktadır.

Düzenleyici ve denetleyici kurumlar tarafindan yapılan düzenlemelere uyumun incelenmesi amaciyla bu kurumlarca bankalarda denetim faaliyetleri gerçekleştirmektedir. Söz konusu denetimler kamu denetimi olarak adlandırılmaktadır (Noyan, 2002: 238). Ek olarak, mevzuat düzenlemelerinin bir gereği olarak bankalarda bağımsız denetçiler (dış denetçiler) tarafından finansal tablo denetimi, bilgi sistemleri (BS) ve bankacılık süreç denetimi gibi denetim çalışmaları da yapılmaktadır. Ayrıca, iç denetim ve iç kontrol bölümlerinde görev yapan iç denetçi, iç kontrolör ve müfettişler (bundan sonra çalışma boyunca iç denetçiler olarak ifade edilecektir) tarafindan denetim faaliyetleri gerçekleştirilmektedir (Kartal, 2017: 112). 
Bankalarda denetim çalışmaları kapsamında genel müdürlük birimlerine, şubelere, bilgi sistemlerine ve teknolojilerine, bankacıllk süreçlerine, faaliyetlere ve personellere yönelik inceleme, sorgulama ve denetim yapılmaktadır (Aslan, 2010: 75). Bu faaliyetlerin tamamlanmasının ardından denetim bulgularını içeren denetim raporu hazırlanmaktadır. Denetim raporları, bankanın en üst yönetim mercii olan yönetim kurulu (YK) ile iç denetim ve iç kontrol bölümlerinin gözetiminden sorumlu olan denetim komitesi (DK), icrai faaliyetlerin en üst makamı olan genel müdürlük makamı ve icrai bölümlerin genel müdür yardımcıları gibi üst düzey yöneticilerden oluşan bir kitleye dağıtılmaktadır. Ayrıca, denetim raporunun ve bulgularının niteliğine bağlı olarak BDDK ve savcılıklar gibi resmi makamlarla da paylaşılmaktadır (Yurtsever, 2009: 20-179; Yüksel vd., 2016: 102).

Bankalarda güvence sağlayan taraflarca gerçekleştirilen kamu denetimi, bağımsız (dış) denetim ve iç denetim (iç denetim ve iç kontrol bölümlerinde görevli iç denetçilerde gerçekleştirilen tüm denetimler) faaliyetleri dikkate alındığında bir bankada bir yıl içinde yüzlerce denetim çalışması gerçekleştirildiği anlaşılmaktadır. Bu denetim çalışmaları sonucunda ise yüzlerce denetim raporu içinde farklı önem derecelerine haiz çok sayıda denetim bulgusu raporlanmaktadır. Söz konusu denetim bulguları denetlenen şube/bölüm yönetiminden YK'ya kadar uzanan yelpazede farklı yönetim kademelerine raporlanmaktadır. Bulguların önem derecesi ve gerçekleştirilen denetimin faaliyetinin türü de bulguların raporlanma sürecini etkileyen önemli hususlardan bazılarıdır.

Bankalardaki denetimlerin ve dolayısıyla denetim bulgularının çokluğu nedeniyle, denetim bulgularının konsolide bazda ve en üst düzeyde takip edilmesi fiili olarak bir zorunluluk haline gelmektedir. Denetim bulgularının konsolide bazda raporlanması ve takip edilmesi, aynı zamanda küresel düzeyde önem kazanmaya başlayan konsolide güvence yaklaşımının da gerekliliklerinden birini oluşturmaktadır (Huibers, 2015: 4; Zhou vd., 2016: 28; Kartal vd., 2018b: 349). BDDK tarafından 25.12.2018 tarihinde taslağı yayınlanan ve 15.03.2020 tarihinde yürürlüğe giren yönetmelik ile bankalarda denetim bulgularına yönelik yeni kurallar getirilmiştir.

$\mathrm{Bu}$ çalışma, diğer düzenlemeleri de göz önünde bulundurmak suretiyle ilgili yönetmelikte yer alan düzenlemelerin denetim bulguları, denetim raporlamaları ve denetim süreçleri açısından bankalar üzerindeki muhtemel etkilerinin değerlendirilmesine yönelik hazırlanmıştır. Ayrıca, yeni düzenlemeyle birlikte denetim bulgularının yönetilmesinde bankaların dikkat etmesi gereken kritik hususlar vurgulanmıştır. Ek olarak, yapılan düzenlemenin yeterliliği ele alınmıştır.

Bilindiği kadarıyla, Türk literatüründe denetim bulgularını yönetmelik çerçevesinde ele alan herhangi bir çalışma bulunmamaktadır. Dolayısıyla, kapsam itibarıyla yapılan bu çalışma öncü olma özelliği taşımaktadır. Ayrıca, bu çalışmanın hazırlanmasıyla birlikte konunun diğer mevzuat ile birlikte yönetmelik bağlamında ele alınması, doğrudan denetim bulgularına yönelik bir çalışmanın ulusal literatüre kazandırılması ve bankacılıkta denetim bulgularına yönelik kavramsal altyapının oluşturulması amaçlanmıştır.

Çalışma beş bölümden oluşmaktadır. Birinci bölüm giriş kısmına ayrılmıştır. İkinci bölümde, kavramsal altyapı ele alınmıştır. Üçüncü bölümde, denetim bulguları ile ilgili literatürde yer alan çalışmalar incelenmiştir. Dördüncü bölümde, yönetmelik başta olmak üzere düzenlemeler bağlamında denetim bulgularının raporlanması ve çözümlenmesi ele alınmıştır. Son bölüm olan beşinci kısımda ise sonuç ve öneriler yer almaktadır.

\section{Kavramsal Altyapı}

Geçmişten günümüze bankalarda iç denetim faaliyetleri gerçekleştirilmektedir. Bununla birlikte, 2000 ve 2001 yıllarında yaşanan krizlerin etkisiyle birlikte yürürlüğe konulan bankacılık sektörü yeniden yapılandırma programı kapsamında bankacılık mevzuatında değişiklikler yapılmıştır. 5411 sayılı BK ile birlikte iç denetim ve iç kontrol bölümleri tarafından bankaların iç denetim faaliyetlerinin gerçekleştirilmesi şeklinde yeniden bir konumlandırma yapılmıştır (BK, 
2005, madde 29-30-32). Dolayısıyla, bankacılık mevzuatından kaynaklanan bir zorunluluk olarak iç denetçiler tarafindan bankalarda denetim faaliyetleri gerçekleştirilmektedir (Kartal, 2017: 112).

\section{a. İç Denetim}

İç denetim faaliyeti "bir kurumun faaliyetlerini geliștirmek ve onlara değer katmak amacını güden bağımsız ve objektif bir güvence ve danışmanlık faaliyeti” şeklinde tanımlanmaktadır. Ayrıca, iç denetim "kurumların risk yönetimi, kontrol ve yönetişim süreçlerinin etkililiğini değerlendirmek ve geliştirmek amacına yönelik sistemli ve disiplinli bir yaklaşım getirerek kurumun amaçlarına ulaşmasına yardımcı olmaktadır” olarak ifade edilmektedir (TIDE, 2019).

Denetim faaliyetleri kapsamına, amacına, gerçekleştirilme sebebine ve denetçilerin statüsüne göre sinıflandırılabilmektedir. Genel olarak ise denetim faaliyetleri denetimin amacına ve denetçilerin statülerine göre sınıflandırılmaktadır. Bu kapsamda, denetim amacına göre faaliyet denetimi, finansal tablo denetimi ve uygunluk denetimi; denetçilerin statülerine göre ise iç denetim, bağımsız (dış) denetim ve kamu denetimi şeklinde bir sınıflandırma söz konusudur (İstanbul Serbest Muhasebeci ve Mali Müşavirler Odası - İSMMMO, 2009: 35). Kamu denetçilerinin ve bağımsız (dış) denetçilerin yanı sıra, iç denetçiler de bankalarda denetim faaliyeti gerçekleştiren bir diğer gruptur. Dolayısıyla, BK'da "Bankalar bütün birim, şube ve konsolidasyona tâbi ortaklıklarını kapsayan bir iç denetim sistemi kurmak zorundadır" hükmüne yer verilmek suretiyle bankaların iç denetim bölümü kurması zorunlu tutulmuştur (BK, 2005, madde 32).

\section{b. İç Kontrol}

Treadway Komisyonu'nu Destekleyen Örgütler Komitesi (The Committee of Sponsoring Organizations of the Treadway Commission- COSO), iç kontrolü "bir kuruluşun yönetim kurulu, yönetimi ve diğer personeli tarafindan etkilenen, faaliyetler, raporlama ve uyumla ilgili amaçlara ulaşılmasına ilişkin makul bir güvence sağlamak üzere tasarlanan bir süreç" olarak tanımlamaktadır (Türkiye İç Denetim Enstitüsü - TIDE), 2013). Bu tanım iç kontrolün esasında süreçlerin bir parças1 olduğunu ve bu nedenle işler ile işlemler yapılırken faaliyetlerin bir parçası olarak gerçekleştirilmesi gerektiğini ifade etmektedir.

Komite tarafından yayınlanmış COSO modeli ise "kontrol ortamı, risk değerlendirme, kontrol eylemleri, bilgi ve iletişim ve izleme eylemleri" olmak üzere beş bileşen üzerine kurulmuştur (TIDE, 2013). Her ne kadar iç kontrolün işler ve işlemler yapılırken gerçekleştirilmesi beklense de Türkiye'de yaşanan krizlerin de etkisiyle iç kontrol, iç denetime benzer şekilde ayrı bir bölüm olarak ve bir nevi denetim bölümü olarak tasarlanmış ve konumlandırılmıştır. Bu husus, BK'da "İç kontrol faaliyetleri yönetim kuruluna bağlı olarak çalışacak iç kontrol birimi ve personeli tarafından yürütülür" hükmü ile kendine yer bulmuştur (BK, 2005, madde 30). Bu kapsamda, iç kontrol bölümü tarafindan da bankalarda önemli oranda denetim faaliyeti gerçekleştirilmektedir.

\section{c. Denetim Raporu ve Denetim Bulguları}

Denetçiler tarafindan gerçekleştirilen denetim çalışmaları sonrasında, denetim ile ilgili hususlarda denetim bulgularını da içerecek şekilde paydaşlarla bilgi paylaşmak için denetim raporu hazırlanmaktadır. Aynı zamanda, uluslararası iç denetim standartları (UiDDS)'ye göre denetim raporu hazırlanması gerekmektedir (TIDE, 2017, 2400 no.lu standart). Denetim bulgularının iletişimi, denetim raporu yoluyla sağlanmaktadır. Bütün denetim çalışmalarında olduğu gibi, iç denetim çalışmalarının sonunda da denetim raporu hazırlanmaktadır.

Gerçekleştirilen denetim çalışmalarının kapsamına göre değişmekle birlikte, bir iç denetim çalışması sonucunda farklı önem derecelerine (düşük, orta, yüksek, çok yüksek) çok sayıda denetim bulgusu ortaya çıkabilmektedir (Özbek, 2012: 990). Söz konusu durum, denetim raporlarının çok uzun olmasına ve bazı önemli bulguların gözden kaçırılarak yeterince önem verilmemesine neden olabilmektedir. Bunu önlemek için önemsiz veya düşük öneme sahip hususlara ilişkin denetim 
bulguları denetim çalışmaları sırasında sözlü iletişim ile paylaşılabilmektedir. Diğer taraftan ise orta, yüksek ve çok yüksek öneme sahip hususlara denetim raporlarında yer verilmektedir.

Denetim bulguları temel olarak "ne olmalı" ve "olan nedir" arasındaki farklılıkları ortaya koymaktadır. Denetim bulguları kıstas, tespit (bulgu), sebepler ve sonuçlar üzerine kurulmalı, diğer bir ifade ile bir denetim bulgusunda bu hususlara yer verilmelidir. Ayrıca, iç denetçiler varsa denetim bulguları ile ilgili çözüm önerilerini, denetim raporunun diğer kısımlarında belirtilmeyen maruz kalınan riskleri ve ilgili görülen diğer bilgileri de paylaşabilmektedirler (Agustiningsih vd., 2017: 182).

\section{d. Denetim Bulgularının Takibi ve Çözümlenmesi}

İlerlemenin gözlenmesi adlı UIDS'nin bir gereği olarak, denetim bulguları izlemeye tabi tutulmalı, diğer bir ifade ile denetim bulgularındaki ilerleme takip edilmelidir. Ayrıca, bu standart uyarınca, ilerlemenin gözlenmesi amacına yönelik olarak bir sistem kurulması gerekmektedir (TIDE, 2017, 2500 no.lu standart). Böylece, takibe konu denetim bulgularının belirlenen çözüm takvimine göre çözümlenmesi amaçlanmaktadır. Denetim bulgularının takip edilmesi ile birlikte bir taraftan denetim ve denetim bulguları konusunda kurum bazında farkındalık sağlanırken, diğer taraftan ise denetim bulgularının önemsizleştirilmesi önlenmektedir.

\section{Literatür Taraması}

Literatürde, yönetmelik bağlamında denetim bulgularını ele alan çalışma bulunmamaktadır. Bununla birlikte, çeşitli çalışmalarda denetim bulgularına kısmen değinildiği görülmektedir. $\mathrm{Bu}$ çalışmalardan bazılarına Tablo 1'de yer verilmiştir. 
Tablo 1: Seçilmiş Bazı Çalışmalar

\begin{tabular}{|c|c|c|c|c|}
\hline Yazar & Yıl & Kapsam & $\begin{array}{l}\text { Çalışmanın } \\
\text { Odağı }\end{array}$ & Sonuç \\
\hline Libby & 1979 & $\mathrm{ABD}$ & Alg1 & 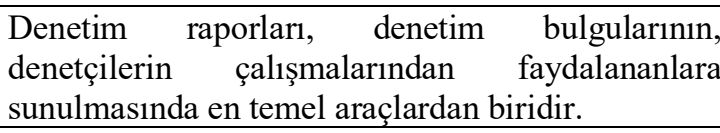 \\
\hline Tuanakota & 2009 & Endonezya & Rol & $\begin{array}{l}\text { Denetim bulguları; kıstas, durum, sebepler ve } \\
\text { sonuçlar olmak üzere dört husus üzerine inşa } \\
\text { edilmelidir. }\end{array}$ \\
\hline Basel & 2012 & Genel & Gözetim & $\begin{array}{l}\text { Bankaların etkin gözetimi için iç denetim bulguları } \\
\text { YK ve DK'ya raporlanmalıdır. }\end{array}$ \\
\hline $\begin{array}{l}\text { Alzeban ve } \\
\text { Sawan }\end{array}$ & 2015 & İngiltere & Raporlama & $\begin{array}{l}\text { Denetim komitelerinin önemli sorumluluklarından } \\
\text { birisi iç denetim bulgularına ve önerilerine yönetim } \\
\text { tarafından verilen cevapların ve alınan aksiyonların } \\
\text { izlenmesi ve gözetimidir. }\end{array}$ \\
\hline $\begin{array}{l}\text { Decaux ve } \\
\text { Sarens }\end{array}$ & 2015 & Belçika & Raporlama & $\begin{array}{l}\text { Denetim bulgularının raporlanması konsolide } \\
\text { güvence uygulamasının gerekliliklerinden birini } \\
\text { oluşturmaktadır. }\end{array}$ \\
\hline $\begin{array}{l}\text { Lenghel ve } \\
\text { Miculescu }\end{array}$ & 2016 & Romanya & İletişim & $\begin{array}{l}\text { Denetim bulguları ve denetimin sonuçları, denetim } \\
\text { raporları vasitasıyla hissedarlarla ve diğer bilgi } \\
\text { kullanıcılarıla paylaşıllmaktadır. }\end{array}$ \\
\hline $\begin{array}{l}\text { Yüksel, Zengin } \\
\text { ve Kartal }\end{array}$ & 2016 & Türkiye & Alg1 & $\begin{array}{l}\text { Denetim bulgularının açık, net, anlaşılabilir olması } \\
\text { ve makul bir sürede denetlenen taraf ile paylaşılarak } \\
\text { tartışılması, iç denetim bölümüne olan bakış açısını } \\
\text { olumlu etkilemektedir. }\end{array}$ \\
\hline $\begin{array}{l}\text { Agustiningsih, } \\
\text { Murni ve Putri }\end{array}$ & 2017 & Endonezya & Etki & $\begin{array}{l}\text { Denetim bulguları, yerel yönetim özelliklerinin } \\
\text { finansal raporlarda açılklanma düzeyine etkisini } \\
\text { yumuşatmaktadır. }\end{array}$ \\
\hline Kartal & 2017 & Türkiye & Yetki & $\begin{array}{l}\text { Bankalarda iç denetçilerinin yetkileri sınırlayan } \\
\text { hususlar DK'ya raporlanmalıdır. }\end{array}$ \\
\hline $\begin{array}{l}\text { Kartal, İbiş ve } \\
\text { Çatıkkaş }\end{array}$ & 2018 & Türkiye & Gözetim & $\begin{array}{l}\text { İç kontrol ve iç denetim bölümlerinden düzenli } \\
\text { rapor alması, önemli bulguları ve bunlara ilişkin } \\
\text { alınan aksiyonları gözden geçirmesi, DK'nın } \\
\text { yeterliliğini etkileyen hususlardan birisidir. }\end{array}$ \\
\hline $\begin{array}{l}\text { Kartal, Depren } \\
\text { ve Kıliç } \\
\text { Depren }\end{array}$ & 2018 & Türkiye & Bağımsızlık & 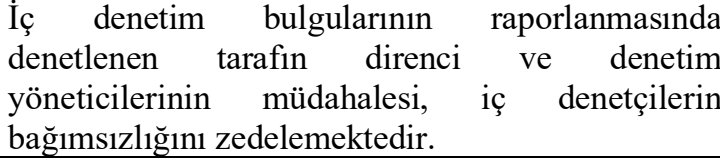 \\
\hline $\begin{array}{l}\text { Kartal ve } \\
\text { Çoban } \\
\text { Çelikdemir }\end{array}$ & $2019 a$ & Türkiye & Eşgüdüm & $\begin{array}{l}\text { Bankalarda şube denetimlerinin eşgüdüm içinde } \\
\text { yapılması denetim bulgularını içeren denetim } \\
\text { raporlarının standartlaştırılmasını sağlamaktadır. }\end{array}$ \\
\hline $\begin{array}{l}\text { Kartal ve } \\
\text { Çoban } \\
\text { Çelikdemir }\end{array}$ & $2019 b$ & Türkiye & $\begin{array}{l}\text { Örgütsel } \\
\text { Konum }\end{array}$ & $\begin{array}{l}\text { DK ile iç denetim ve iç kontrol bölümleri arasında } \\
\text { bulunan üst düzey yönetici pozisyonu, denetim } \\
\text { bulgularının doğrudan YK ve DK'ya } \\
\text { raporlanmasını zorlaştırmaktadır. }\end{array}$ \\
\hline
\end{tabular}

Kaynak: Tablo yazarlar tarafindan oluşturulmuştur.

Libby (1979), bankacıların ve denetçilerin algılarına yönelik çalışmasında, denetim bulguların içeren denetim raporlarının denetçiler, denetlenenler ve denetim çalışmalarından faydalananlar arasındaki iletişimde kullanılan en temel araçlardan biri olduğunu ifade etmiştir.

Basel (2012), bankaların etkin gözetimine ilişkin olarak temel ilkeleri yayınlamıştır. Bu kapsamda iç denetim bulgularının YK'ya ve DK'ya raporlanması gerektiği, böylece iç denetim bölümlerinin bağımsızlıklarının sağlanacağını düzenlemiştir. 
Decaux ve Sarens (2015), konsolide güvence yaklaşımı çerçevesinde yaptıkları çalışmalarında, konsolide güvence yaklaşımının uygulanabilmesi için birçok gereklilik bulunduğu ve denetim bulgularının raporlanmasının da bu gerekliklerinden biri olduğunu ifade etmişlerdir.

Lenghel ve Miculescu (2016), denetim bulgularının raporlanması ve iletişimine yönelik çalışmalarında, denetim bulgularının iletişiminin denetim raporlarıyla yapıldığı ve denetim raporları vasıtasıyla bulguların hissedarlarla ve ilgili diğer rapor kullanıcıları ile paylaşıldığı sonucuna ulaşmışlardır.

Yüksel, Zengin ve Kartal (2016), iç denetim bölümüne banka çalışanlarının bakış açısını içeren algı odaklı gerçekleştirdikleri çalışmalarında, denetim bulgularının açık, net, anlaşılabilir olması, denetim kanıtlarının adil bir şekilde değerlendirilmesi, denetim çalışmasının tamamlanmasından makul bir süre önce denetlenen tarafla paylaşılması ve bulguların tartışılması gibi hususların iç denetim bölümüne bakışı olumlu etkilediğini belirlemişlerdir.

Kartal (2017), iç denetim ve iç kontrol bölümünde görev yapan banka denetçilerinin yetki sınırlarına yönelik çalışmasında, denetçilerin bilgilere erişiminin engellenmesi ve talep edilen bilgilerin makul gerekçelere dayanmaksızın denetçiye verilmemesi gibi hususların banka denetçilerinin yetki kullanımını sınırladığı sonucuna ulaşmış ve hususların ivedilikle banka denetim komitesine raporlanması gerektiği belirtilmiştir.

Kartal, Depren ve Kılıç Depren (2018), iç denetim ve iç kontrol bölümü üzerine bağımsızlık odaklı gerçekleştirdikleri çalışmalarında, denetim yöneticilerinin denetim bulgularının raporlanmasına yönelik müdahalelerinin ve denetlenen tarafin denetim bulgularına gösterdikleri direncin iç denetçilerin bağımsızlı̆̆ına zarar verdiğini belirlemiş̧tir.

Kartal, İbiş ve Çatıkkaş (2018), iç sistemleri de kapsayacak şekilde denetim komiteleri üzerine yeterlilik odaklı çalışma yapmışlardır. DK'nın iç denetim ve iç kontrol bölümlerinden düzenli şekilde rapor alması, raporlarda yer alan önemli bulguların ve bu bulgulara ilişkin alınan aksiyonların gözden geçirilmesi hususlarının DK'nın yeterliliğini etkileyen hususlardan olduğu sonucuna ulaşmışlardır.

Kartal ve Çoban Çelikdemir (2019a), bankaların iç denetim ve iç kontrol bölümleri tarafından gerçekleştirilen şube denetimleri üzerine eşgüdüm odaklı çalışma yapmışlardır. İki bölüm tarafından gerçekleştirilen şube denetim faaliyetlerinin eşgüdüm içinde sürdürülmesi halinde birçok fayda sağlanacak olup, bu faydalardan biri de denetim bulgularını içeren denetim raporlarının standartlaştırılması olacaktır.

Kartal ve Çoban Çelikdemir (2019b), bankaların iç denetim bölümlerinin organizasyonel konumunu ele alan çalışma yapmışlardır. DK ile iç denetim ve iç kontrol bölümleri arasında üst düzey yönetici bölümlerinin bulunduğu banka örnekleri belirlenmiş olup, söz konusu yapı iç denetçilerin denetim bulgularını doğrudan YK'ya ve DK'ya raporlama yapmasını zorlaştırmaktadır.

Literatürde yer alan çalışmalar değerlendirildiğinde, doğrudan denetim bulgularını konu edinen ve denetim bulgularının çözümlenmesine odaklanan bir çalışma bulunmadığı, bununla birlikte farklı çalışmalarda denetim bulgularına değinildiği görülmektedir. Bu çalışma ise doğrudan denetim bulgularına ve denetim bulgularının çözümlenmesine yönelik olarak hazırlanmıştır. $\mathrm{Bu}$ kapsamda, diğer mevzuat düzenlemelerini göz önünde bulundurmak ve yönetmelik düzenlemeleri temel alınmak suretiyle bankalarda denetim bulgularının raporlanması ve çözümlenmesi ele alınmıştır.

\section{Bankalarda Denetim Bulgularının Raporlanması ve Çözümlenmesi}

Bankalarda denetim bulgularının raporlanması ve çözümlenmesi ile ilgili olarak çeşitli unsurlardan oluşan bir düzenleyici çerçeve bulunmaktadır. Bu hususta, bankacılık mevzuatında yer alan düzenlemelerde çeşitli hükümler bulunmaktadır. Ayrıca, UIDSS'de de konu ile ilgili çeşitli 
kurallar yer almaktadır. Bu kapsamda, bu bölümün ilk kısmında denetim bulgularının raporlanması ve çözümlenmesi ile ilgili olarak UiDS'de yer alan hükümler, ikinci kısımda ise Türk bankacılık mevzuatında yer alan mevcut düzenlemeler ele alınmıştır. Üçüncü kısımda, yönetmelik ile getirilen düzenlemeler ve bankalar üzerindeki muhtemel etkileri değerlendirilmiştir. Son kısımda ise yönetmelik kapsamında bankaların dikkat etmesi gereken hususlar vurgulanmıştır.

\section{a. UIDS Düzenlemeleri}

UIDS genel hatları ile nitelik ve performans standartları olarak iki grubu ayrılmaktadır (TIDE, 2017). Denetim bulgularının raporlanması ve çözümlenmesi bakış açısından UIDSS ele alındığında, çeşitli standartların bulunduğu ve bu standartların performans standartları grubunda yer aldığı görülmektedir.

Denetim bulgularının raporlanması ve çözümlenmesi ile ilgili UIDS kapsamında yer alan ilk standart, 2400 no.lu sonuçların raporlanması başlıklı standarttır. Bu standart, iç denetçilerin, gerçekleştirdikleri denetim faaliyetleri sonucunda görev sonuçlarını raporlamalarını gerekli k1lmaktadır (TIDE, 2017, 2400 no.lu standart).

UIDS kapsamındaki ikinci standart, 2410 no.lu raporlama kıstasları başlıklı standarttır. Bu standart, raporlama yapılırken denetim görevinin hedeflerinin, kapsamının ve sonuçlarının raporlamada yer alması gerektiğini düzenlemektedir (TIDDE, 2017, 2410 no.lu standart).

UIDS kapsamındaki üçüncü standart, 2420 no.lu raporlama kalitesi başlıklı standarttır. $\mathrm{Bu}$ standart, raporlamanın doğru, objektif, açık, özlü, tam ve zamanında sunulmasını gerekli kılmaktadır (TIDE, 2017, 2420 no.lu standart).

UİDS kapsamındaki dördüncü standart, 2421 no.lu hata ve eksiklikler başl1klı standarttır. Bu standart, nihai denetim raporunun önemli bir hata veya eksiklik içermesi durumunda, düzeltilmiş raporun hazırlanarak hatalı raporu alan taraflara iletilmesini zorunlu kılmaktadır (TIDE, 2017, 2421 no.lu standart).

UIDS kapsamındaki beşinci standart, 2440 no.lu sonuçların dağıtımı başlıklı standarttır. Bu standart, iç denetim yönetici tarafından görev sonuçlarının uygun taraflara raporlanması gerektiğini düzenlemektedir (TIDE, 2017, 2440 no.lu standart).

UIDS kapsamındaki son standart ise, 2500 no.lu ilerlemenin gözlenmesi başlıklı standarttır. $\mathrm{Bu}$ standart ise yönetime raporlanan bulguların akıbetinin izlenmesi için bir sistem kurulmasını zorunlu tutmaktadır (TIDE, 2017, 2500 no.lu standart).

Genel hatlarına yukarıda yer verilen 6 adet performans standardı birlikte değerlendirildiğinde, UIDS'nin denetim bulgularının raporlanması ve çözümlenmesi konularında aksiyon alınmasını gerektirdiği ortadadır. Bu nedenle, bankalarda iç denetim ve iç kontrol bölümlerinin üst yöneticileri ile bu bölümlerin gözetiminden sorumlu olan denetim komitelerinin ve yönetim kurullarının üyeleri, denetim bulgularının raporlanması ile çözümlenmesi konusuna özel önem göstermeli ve bu konuda somut ilerleme sağlanması için gerekli zamanı ayırarak çalışmalar yapmalıdirlar.

\section{b. Türk Bankacılık Mevzuatındaki Mevcut Düzenlemeler}

2000 ve 2001 yıllarında yaşanan bankacılık krizlerinin de etkisiyle, 5411 sayılı BK'nın yürürlüğe girmesiyle birlikte, bir taraftan bankaların iç denetim ve iç kontrol bölümlerinin bağımsız birer bölüm olarak yapılandırılması zorunlu tutulmuş, diğer taraftan ise BDDK'ya ikincil düzenleme yapma yetkisi verilerek gerek duyulması halinde yeni düzenlemeler yapılmasının önü açılmıştır.

BDDK tarafından denetime ve denetim bulgularının raporlanmasına ilişkin çeşitli düzenlemeler yapılmıştır. Yönetim beyanı, BS ve bankacılık süreçlerinin denetimi, BS sızma testleri ve bağımsız denetim takip sistemi BDDK'nın denetim ile ilgili söz konusu düzenlemelerinden 
bazılarıdır. Diğer taraftan, iç denetim ile ilgili BDDK tarafından yapılan en önemli düzenleme Bankaların İç Sistemleri ve İçsel Sermaye Yeterliliği Değerlendirme Süreci Hakkında Yönetmelik (İç Sistemler Yönetmeliği)'dir.

Geçici ve ek maddeleri ile birlikte toplamda 67 maddeden oluşan İç Sistemler Yönetmeliği’nde denetim bulgularının raporlanması ve çözümlenmesi ile ilgili olarak çeșitli hükümler yer almaktadır. İç kontrol birimi başlıklı 19. maddede, iç denetçiler tarafından gerçekleştirilen kontrol çalışmalarının sonuçlarının en geç 3 ayda 1 olmak üzere DK'ya raporlanacağı belirtilmiştir (BDDK, 2014, madde 19). Diğer taraftan, iç denetim raporları başlıklı 31. maddede aşağıdaki hususlar düzenlenmiştir (BDDK, 2014, madde 31):

Denetim raporları, bir birimin veya faaliyetin kanun ve ilgili diğer mevzuat ile banka içi politika ve uygulama usullerine uygunluğu, işletilen süreçlerin ve iç kontrollerin etkinliği ve alınması gerektiği düşünülen düzeltici işlemler hakkında üst yönetime bilgi verecek mahiyette düzenlenmelidir.

İç denetçiler bulgularını ve önerilerini ilgili taraflarla paylaşmak, denetim raporlarını acil bir durum öngörülmediği sürece denetim çalışması tamamlandıktan sonra mümkün olduğu kadar kısa süre içinde iç denetim birimi aracılığıyla DK'ya ve YK'ya ulaştırmakla yükümlüdür. hazırlanmalıdır.

İç denetim raporları denetlenen alan ve iç denetim gereklerine uygun olarak

$>\quad$ Taslak rapor ilgili bölümle görüşülmelidir.

$>\quad$ Nihai rapor, gerekli tedbirlerin alınması için ilgililerle paylaşılmalıdır.

Ek olarak, yine 31. maddede, iç denetim birimi tarafindan, gerçekleştirilen faaliyetlere ilişkin asgari 3 ayda 1 olmak üzere DK'ya bir rapor sunulması, bu raporun DK mütalaası ile birlikte YK'ya sunulması gerektiği düzenlenmiştir. Ayrıca, İç Sistemler Yönetmeliği'nin 32. maddesinde, iç denetim raporlarında yer verilen hususların daha sonra izlemeye konu edilmesi, izleme sonuçlarının DK'ya raporlanması ve sonraki denetim planı çalışmalarında dikkate alınması gerektiği düzenlenmiştir (BDDK, 2014, madde 32).

İç Sistemler Yönetmeliği'nde yer alan ve yukarıda genel hatlarına yer verilen bu düzenlemeler değerlendirildiğinde, denetim faaliyetleri sonucunda rapor düzenlenmesi ve bu raporlarda bulgulara yer verilerek bunların iletişiminin yapılması gerektiği düzenlenmişsir. Bununla birlikte, söz konusu düzenlemede, denetim bulgularının DK ve YK tarafından özet bir rapor içinde ele alınacağı ve yeterli önemin verilmeyeceği ortadadır. Bu nedenle, denetim bulgularının banka üst yönetimi nezdinde daha dikkatli ele alınmasını sağlayacak ilave düzenleme yapılmasına ihtiyaç bulunmaktadır.

\section{c. Yönetmelik İle Getirilen Düzenlemeler ve Bankalara Muhtemel Etkileri}

\section{i. Yönetmelik'in Kapsamı}

BDDK tarafindan 25.12.2018 tarihinde taslağı yayınlanan Yönetmelik, 15.03.2020 tarihinde Resmi Gazetede yayınlanmış ve yürürlük tarihi 01.07.2020 olarak belirlenmiştir. Yönetmelik 45 temel madde ile yürürlük ve yürütmeye ilişkin 2 ek maddeden oluşmaktadır.

Yönetmelik'te denetim bulguları ile ilgili hükümler ağırlıklı olarak ikinci kısımda yer almaktadır. Yönetmelik kapsamına özet olarak Tablo 2'de yer verilmiştir. 
Tablo 2: Özet Yönetmelik Kapsamı*

\begin{tabular}{|c|l|}
\hline Madde No & \multicolumn{1}{|c|}{ Madde Başlı̆̆ı } \\
\hline Birinci Kısım: Başlangıç Hükümleri \\
\hline 3 & Tanımlar ve kısaltmalar \\
\hline İkinci Kısım: Bilgi Sistemlerine İlişkin Risk Yönetimi ve Kontrollerin Tesisi \\
\hline Yedinci Bölüm: BS İç Kontrol ve İç Denetim Faaliyetleri \\
\hline 30 & BS iç kontrol faaliyetleri \\
\hline 31 & BS iç denetim faaliyetleri \\
\hline 32 & Bulguların takibi ve güvence sağlanması \\
\hline 33 & Personelin eğitilmesi ve kaynak tahsisi \\
\hline
\end{tabular}

*: Bu kapsamda, sadece denetim bulguları ile ilgili olan maddelere yer verilmiştir.

Kaynak: BDDK, 2020.

Tablo 2'de özet olarak yer verildiği üzere, yönetmelikte denetim bulgularına yönelik çeşitli maddeler yer almaktadır. Söz konusu maddelerde, bankaların denetim bulgularının raporlanması ve çözümlenmesine yönelik düzenlemelere yer verilmiştir.

\section{ii. Yönetmelik Düzenlemeleri}

Yönetmelik temel olarak bankaların bilgi sistemleri ve elektronik faaliyetleri ile ilgili hususları düzenlemektedir. Bununla birlikte, bu çalışmanın odak noktası itibarıyla, ilgili yönetmeliğin sadece denetim bulguları ile ilgili maddeleri ele alınmıştır. Bu kapsamda, yönetmelikte yer alan denetim bulgularının raporlanmasına ve çözümlenmesine yönelik düzenlemelerin detaylı bir şekilde incelenmesi gerekmektedir.

Yönetmelik'in bilgi sistemleri iç kontrol faaliyetleri başlıklı 30. maddesinde aşağıdaki hususlar düzenlenmiştir (BDDK, 2020, madde 30):

"Gerçekleştirilen kontroller sonucunda belirlenen eksikliklerin giderilmesi ve aksiyon alınması amacıyla ilgili birimlere ve üst yönetime bildirimde bulunulması

Kontroller sonucunda gerekli olduğu anlaşılan süreçlere veya sistemlere ilişkin iyileştirme önerilerinin ilgili birimlere ve üst yönetime bildirilmesi

Bilgi teknolojileri yönetimi ve dış hizmet alımından kaynaklı risklerin takibinin sağlanmasına yönelik üst yönetim, denetim komitesi ve iç kontrol birimi yöneticisine periyodik olarak raporlama yapılmas1

BS iç kontrol faaliyetleri kapsamında yapılan periyodik kontrollerin kayıt altına alınması ve yapılan kontrollere ilişkin çalışma kanıtlarının en az üç yıl banka nezdinde saklanması

BS iç kontrol fonksiyonu oluşturulmasına, bu fonksiyona sorumlu ve ekip atanmasına, bu kişilerin niteliklerine ve BS iç kontrol planına yönelik düzenlemeler de yapılmıştır."

Yönetmelik'in bilgi sistemleri iç denetim faaliyetleri başlıklı 31. maddesinde "BS iç denetim fonksiyonu oluşturulmasına, bu fonksiyona sorumlu ve ekip atanmasına, bu kişilerin niteliklerine, BS iç denetim planına ve denetim döngüsü”ne yönelik hususlar düzenlenmiştir (BDDK, 2020, madde 31):

Yönetmelik'in bulguların takibi ve güvence sağlanması başlıklı 32. maddesinde aşağıdaki hususlar düzenlenmiştir (BDDK, 2020, madde 32):

"DK, BS iç kontrol, BS iç denetim ve diğer BS denetim çalışmaları sonucu tespit edilen bulguların ele alınması konusuna yeterli zamanı ayırır. Bu çalışmalar sonucu tespit edilen kritik konuları DK bizzat gözden geçirir ve gerekli önlemlerin alınması konusunda üst yönetime rehberlik eder. DK üyelerinin kompozisyonu, BS iç kontrol ve BS iç denetim raporlarını ve 
bulgularını uygun bir şekilde değerlendirebilecek mesleki tecrübeye veya bilgi birikimine sahip olacak şekilde oluşturulur.

Banka, BS iç kontrol, BS iç denetim ve diğer BS denetim çalışmaları sonucu tespit edilen bulguların aksiyon planına bağlanarak takip edilmesini sağlar. Bulguların kapatılmasına yönelik olarak aksiyon planında hedef tamamlanma tarihi atanamayan, aşılan, aşma süresi bir seneden fazla uzatılan veya iptal edilen bulgular denetim komitesine düzenli olarak raporlanır ve bu bulgular denetim komitesinde kritik konular olarak ele alınır.

BS iç kontrol ve iç denetim fonksiyonu, tespit ettiği bulguların giderilmesine yönelik olarak denetlenen ilgili birim tarafından alınabilecek önlemler ve aksiyonlara yönelik önerilerde bulunur ya da denetlenen ilgili birimin bu yönde almayı planladığı aksiyonlar konusunda mutabık kalır. Öneri ve aksiyonların uygulamasının tamamlanması neticesinde kapatılabilir duruma gelen bulgulara ilişkin nihai karar, bulgunun sahibi olan BS iç kontrol ya da BS iç denetim fonksiyonu tarafindan incelenmesi neticesinde verilir.

BS iç kontrol ve iç denetim fonksiyonları tarafından gerçekleştirilen çalışmalar sonucunda, bankanın BS kontrollerinin incelenmesi ve bağımsız denetim kuruluşları tarafından gerçekleştirilen çalışmalardan bağımsız olarak bu kontroller hakkında bütün önemli kontrol eksikliklerini ortaya koymak üzere bir değerlendirme yapılması ve bu kapsamda;

- Bankanın BS kontrollerinde, İ̧ Sistemler Yönetmeliğinin "iç kontrol sistemi" başlıklı ikinci kısmı ile Yönetmelik'te belirtilen usul ve esaslar açısından etkinlik, yeterlilik veya uyumluluğa engel teşkil edecek herhangi bir önemli kontrol eksikliğinin bulunmadiğ

- $\quad$ Finansal tablolarda önemli yanlış beyana sebep olan veya başta finansal veriler olmak üzere banka açısından hassasiyet arz eden verilerin bütünlüğ̈̈, tutarlılı̆̆l, güvenilirliği, gereken durumlarda gizliliği ve faaliyetlerin sürekliliğini önemli ölçüde etkileyen bir durumun ya da yöneticiler ile iç kontrol sisteminde kritik görevleri bulunan diğer görevlilerin dâhil olduğu bir suiistimalin ya da yolsuzluğun bulunmadı̆ğ,

- Tespit edilen bulgular arasinda yukarıdaki iki bent kapsamına giren hususlar varsa, bunların hepsinin DK'ya ve YK'ya raporlandiğ

hususlarında güvence sağlanması esastır.

Yönetmelik'in personelin eğitilmesi ve kaynak tahsisi başlıklı 33. maddesinde aşağıdaki hususlar düzenlenmiştir (BDDK, 2020, madde 33):

"BS iç kontrol ve iç denetim faaliyetlerinin eşgüdümünün sağlanmas1,

$>\quad$ BS iç kontrol ve iç denetim faaliyetlerinin etkinliği için yeterli nitelikte kaynak temini, personelin düzenli ve sürekli eğitimi”".

Son olarak, ilgili yönetmlik önetmelik düzenlemeleri 01.07.2020 tarihinde yürürlüğe girecek olup, bu kapsamda bankaların söz konusu hükümlere en geç anılan tarihine kadar uyum sağlamaları gerekmektedir (BDDK, 2020, madde 46).

\section{iii. Düzenlemelerin Muhtemel Etkileri ve Yönetmelik'in Değerlendirilmesi}

Yönetmelik'in denetim bulguları açısından bankalar üzerindeki etkileri genel hatlarıyla; i) bankaların BS iç kontrol ve iç denetim çalışmalarının eşgüdüm içinde planlanması, ii) yeterli nitelikte kaynak temini, personelin düzenli ve sürekli eğitimi, iii) denetim bulgularının tamamlanma durumunun düzenli olarak takip edilmesi, iv) sonuçların düzenli olarak üst yönetime, DK'ya ve YK'ya raporlanmas1, v) DK'nın bulgular için yeterli zaman ayırması, vi) tamamlanma tarihini aşan bulguların DK tarafindan kritik konular ele alınması, hususları gelmektedir. Bununla birlikte, söz 
konusu faaliyetlerin yerine getirilebilmesi için bankalar DK'nın üye kompozisyonunu gözden geçirmeli ve bu hususta eksiklik gözlemliyorlarsa DK'ya bilgi sistemleri konusunda uzman üyeler atamalıdırlar. Bu durum aynı zamanda bankaların genel kurul ve YK üye seçimi hususlarını da tetikleyecektir. Bankaların ihtiyaçlarına göre YK üye sayısının artırılması da gündeme gelebileceklerdir.

Ek olarak, "kontroller sonucunda gerekli olduğu anlaşılan süreçlere veya sistemlere ilişkin iyileştirme önerilerinin ilgili birimlere ve üst yönetime bildirilmesi, BS iç kontrol faaliyetleri kapsamında yapılan periyodik kontrollerin kayıt altına alınması ve yapılan kontrollere ilişkin çalışma kanıtlarının en az üç yıl banka nezdinde saklanması, BS iç denetim döngüsünün iki yılı aşmaması" da bankalara yönelik getirilen yeni düzenlemelerden bazılarıdır.

Ayrıca, BS kontrollerinde önemli kontrol eksikliği olmadığı, finansal tablolarda hata ve hileye neden olan bir suiistimal ve yolsuzluk bulunmadığı, şayet bunlardan biri varsa DK'ya ve YK'ya raporlandığı hususlarını da kapsayacak şekilde genel bir değerlendirme yapılması gerekmektedir. Dolayısıyla, BS iç kontrol ve iç denetim faaliyetleri, bankaların tüm BS süreç ve faaliyetlerini baştan sona kapsamak zorundadır.

Diğer taraftan, yukarıdaki hususların yanı sıra bankalar BS iç kontrol ve iç denetim fonksiyonlarını yeniden yapılandırmak zorunda kalacaklardır. Nitekim ilgili yönetmeliğin 30. ve 31 . maddeleri bu fonksiyonların banka organizasyon yapısında diğer iç kontrol ve iç denetim fonksiyonlarından ayrılmasını gerekli kılmaktadır (BDDK, 2020, madde 30-31). Yönetmelik uyarınca, bankalar BS iç kontrol ve iç denetim fonksiyonlarına BS kontrol ve denetiminde deneyimli birer sorumlu (yönetici) ve yeterli sayı ile nitelikte personel atamak durumunda kalacaklardır. Ayrıca, söz konusu personelin ilgili yönetmelikte belirlenen kural ve sınırlamalara uygun şekilde sürekli eğitimi sağlanmalıdır.

Yönetmeliğin, bankalar üzerinde yukarıda belirtilen etkileri oluşturması muhtemeldir. Bununla birlikte, süreç ilerlemeden ve ilgili yönetmelik yürürlüğe girmeden önce yönetmeliğin değişikliklere tabi tutulması gerektiği düşünülmektedir. Nitekim bankalarda sadece BS iç kontrol ve denetimleri yapılmamakta, bankaların şubelerine, genel müdürlük birimlerine, ürün ile hizmetlerine ve bankacılık süreçlerine yönelik güvence faaliyetleri de gerçekleştirilmektedir. Dolayısıyla, yapılan düzenleme sadece BS iç kontrol ve iç denetim bulgularına yönelik kurallar getirmesi yönüyle eksiktir. İlgili yönetmeliğin tüm iç kontrol ve iç denetim bulgularını kapsayacak şekilde genişletilmesi önerilmektedir.

Yönetmeliğin tüm iç kontrol ve iç denetim bulgularını kapsayacak şekilde genişletilmesiyle birlikte sadece BS denetim faaliyetlerine ve denetim bulgularına değil, tüm denetim faaliyetlerine ve bulgularına yönelik bankalarda gerekli önemin verilmesi sağlanabilecektir. İlgili yönetmeliğin mevcut haliyle kalması durumunda ise, bankalarca BS haricindeki bulgulara yeterli önem verilmemeye devam edileceği dikkate alındığında BS haricindeki riskler yüksek seviyede devam edecektir. Yönetmeliğin kapsamının genişletilmesi halinde ise, bankaların karşı karşıya kalabileceği tüm risk türlerinde kayda değer bir azalış sağlanabilecektir.

\section{d. Bankaların Dikkat Etmesi Gereken Hususlar}

15.03.2020 tarihinde yayınlanan ve 01.07.2020 tarihinde yürürlüğe girecek olan ilgili yönetmelik, bankalarda denetim bulguları açısından önemli kuralları düzenlemektedir. Bankalarda denetim bulguları açısından çeşitli kurallar ortaya koyan yönetmelik, doğal olarak bankalar üzerinde çeşitli etkiler oluşturacaktır. Bu kapsamda, bankaların dikkat etmesi gereken hususlar bulunmaktadır.

İlk husus olarak, ilgili yönetmeliğin yürürlük tarihi (01.07.2020) gelmeden önce, bankalar gerekli çalışmaları tamamlamalı ve başta organizasyonel değişiklikler ile kaynak tahsisi olmak üzere gerekli adımları atmalıdırlar. 
İkinci husus olarak, bankaların DK üyelerinin nitelikleri BS iç kontrol ile iç denetim faaliyetlerinin ve bulgularının gözetimi için yetersizse, bankaların mevcut YK üyelerinin nitelikleri göz önünde bulundurularak yeni üyelerin araştırılması, seçilmesi ve DK üyelerinin değiştirilmesi hususları hassasiyetle ele alınmalıdır. Ayrıca, bu hususta 01.07.2020 olan uyum sürecinin kısa olduğu dikkate alındığında, bu maddeye özel olarak daha uzun bir geçiş süreci tanınmasının düzenleyici otorite tarafindan değerlendirilmesi faydalı olacaktır.

Üçüncü husus olarak, ilgili yönetmeliğin önemli kurallar getirdiği ve geçiş sürecinin kısalığ1 dikkate alındığında, bankaların hızlıca aksiyon almaya başlaması, gerekli hazırlıkların zamanında yapılması açısından önem taşımaktadır.

Dördüncü husus olarak, denetim bulgularının çözümlenmesi konusunun salt olarak icrai bölümlere bırakılması halinde mesafe kat edilmesi mümkün görülmemektedir. Dolayısıyla, bu konuda iç kontrol ve iç denetim bölümleri de sorumluluk üstlenmelidir.

Beşinci husus olarak, denetim bulgularının çok çeşitli, farklı kapsamlı ve çok fazla sayıda olduğu dikkate alındığında, hangi tür bulguların hangi seviyelerde takibinin yapılacağı önem taşımaktadır. Bu kapsamda düşük riskli bulgular icrai bölüm seviyesinde takip edilirken orta ve yüksek riske sahip bulgular mutlaka üst yönetim, DK ve YK seviyesinde gözetilmelidir. Ayrıca, kritik bulgular DK tarafindan gözetilirken, bu kapsama orta seviyeli bulgular da eklenmelidir.

Altıncı husus olarak, denetim bulgularının sayı ve kapsamı dikkate alındığında, tüm banka bazında uygulanacak bir bulgu takip sisteminin kurulması ve işletilmesi önem taşımaktadır. Ek olarak, tüm iç kontrol ve iç denetim bulguları BDDK nezdinde konsolide olarak izlenerek, belirli konularda sistemik risk olup olmadığı da değerlendirilmelidir.

Yayınlanan yönetmeliğin yeni olduğu, uygulamada farklılıkların ve aksaklıkların oluşabileceği göz önünde bulundurularak, gelişmeler BDDK tarafından yakından izlenmeli ve olumsuzlukların ortaya çıkma ihtimalinin belirmesi halinde hızlı çözümler geliştirilerek gerekli tedbirler alınmalıdır.

\section{Sonuc ve Öneriler}

Bankalarda gerçekleştirilen birçok güvence faaliyetleri bulunmaktadır. Dış tarafların yanı sıra iç taraflar olan iç kontrol ve iç denetim bölümlerince de güvence faaliyetleri yerine getirilmektedir. Bu faaliyetlerin birer sonucu olarak birçok denetim raporu düzenlemekte, farklı önem ve risk seviyelerine haiz yüzlerce denetim bulgusu ortaya çıkmaktadır. Dolayısıyla, denetim bulgularının konsolide bazda ele alınması ve üst yönetim tarafından gözetimi bir zorunluluk teşkil etmektedir. Nitekim bankalar ekonomiler açısından sistemik öneme haiz kuruluşlar olduğu için bu kuruluşlarda ortaya çıkacak sorunlar tüm ülkeyi derinden etkileyecektir.

Çalışmada, BDDK tarafından 15.03.2020 tarihinde yayınlanan yönetmelik çerçevesinde denetim bulgularının raporlanması ve çözümü ele alınmıştır. Aynı zamanda, araştırmada kavramsal incelemenin yanı sıra ilgili yönetmeliğin bankalara muhtemel etkilerine ve bankaların dikkate etmesi gereken hususlara da yer verilmiştir.

Çalışma sonucunda, iç kontrol ve iç denetim tarafından gerçekleştirilen güvence faaliyetleri sonucunda ortaya çıkan denetim bulgularının bir bulgu takip sistemi aracılığıyla konsolide bazda raporlanması, banka üst yönetimi tarafindan gözetilmesi ve bu faaliyetlerin sadece bilgi sistemleri bulguları değil, tüm denetim bulguları için sürdürülmesi gerektiği ortaya konulmuştur. Bu kapsamda, yapılan düzenlemenin yeterliliği ele alınmış ve ilgili yönetmelikte değişiklik yapılması önerilmiştir. Ayrıca, 01.07.2020 tarihinde kadar olan geçiş sürecinin bankalar tarafından iyi değerlendirilmesi, bankalar ve BDDK nezdinde tüm bulguları kapsayacak konsolide bulgu takip sistemleri kurulması, sürecin BDDK tarafından gözetilmesi ve gerektiğinde tereddüt gösterilmeden ilave tedbirler alınması da önerilmektedir. Buna karşın, ilgili yönetmelik bankalarda denetim bulgularının raporlanması, 
çözümlenmesi ve üst yönetim tarafından daha dikkatli bir şekilde ele alınması açısından katkı sağlayacak niteliktedir.

Son olarak, bu çalışma Türkiye'de doğrudan denetim bulgularının çözümlenmesini ele alan özgün bir çalışmadır. Aynı zamanda, araştırma literatür altyapısı oluşturmaktadır. Hiç şüphesiz ilgili yönetmeliğe geçiş sürecinin tamamlanması, ilk uygulamaların ortaya çıkması ve gözlemlenmesi, denetim bulgularına yönelik gerek bankalar gerekse BDDK nezdinde veri tabanlarının oluşması sonrasında yeni çalışmaların yapılması literatürün derinleştirilmesi açısından faydalı olacaktır.

\section{Kaynakça}

Agustiningsih, S. W., Murni, S., \& Putri, G. A. (2017). Audit Findings, Local Government Characteristics, and Local Government Financial Statement Disclosure. Review of Integrative Business and Economics Research, 6(3), 179-187.

Alzeban, A., \& Sawan, N. (2015). The Impact of Audit Committee Characteristics on the Implementation of Internal Audit Recommendations. Journal of International Accounting, Auditing and Taxation, 24, 61-71.

Aslan, Bayram. (2010). Bir Yönetim Fonksiyonu Olarak İç Denetim. Sayıştay Dergisi, 77, 63-86.

Basel. (2012). Core Principles for Effective Banking Supervision. http://www.bis.org/publ/bcbs230.pdf, Erişim Tarihi: 25.10.2019.

BDDK. (2014). Bankaların İç Sistemleri ve İçsel Sermaye Yeterliliği Değerlendirme Süreci Hakkında Yönetmelik, 11.07.2014 tarihli ve 29057 sayılı Resmi Gazete.

BDDK. (2020). Bankaların Bilgi Sistemleri ve Elektronik Bankacılık Hizmetleri Hakkında Yönetmelik, 15.03.2020 tarihli ve 31069 sayılı Resmi Gazete.

BK. (2005). 5411 sayılı Bankacılık Kanunu, 01.11.2005 tarih ve 25983 sayılı Resmi Gazete.

Decaux, L., \& Sarens, G. (2015). Implementing Combined Assurance: Insights from Multiple Case Studies. Managerial Auditing Journal, 30(1), 56-79.

Dinçer, H., Hacioğlu, Ü., \& Yüksel, S. (2016). Performance Assessment of Deposit Banks with CAMELS Analysis Using Fuzzy ANP-MOORA Approaches and an Application on Turkish Banking Sector. Asian Journal of Research in Business Economics and Management, 6(2), 32-56.

Huibers, S. C. J. (2015). Combined Assurance: One Language, One Voice, One View. IIA CBOK Raporu.

İSMMMO. (2009). Uluslararası Denetim Standartları Kapsamında Bağımsız Denetim. Yayın No: 130. İSMMMO Yayınları.

Kartal, M. T. (2017). Düzenlemeler Açısından Banka Denetçilerinin Yetki Sınırlarının Belirlenmesi Üzerine Bir İnceleme. Bankactlar Dergisi, 102, 111-131.

Kartal, M. T., İbiş, C., \& Çatıkkaş, Ö. (2018). Adequacy of Audit Committees: A Study of Deposit Banks in Turkey. Borsa İstanbul Review, 18(2), 150-165.

Kartal, M. T., Depren, Ö., \& Kılıç Depren, S. (2018a). Türk Bankacıllk Sektöründe İç Denetçilerin Bağımsızlı̆̆ 55(642), 41-67. 
Kartal, M. T., Çatıkkaş, Ö., \& Çoban Çelikdemir, N. (2018b). Bankacılıkta Konsolide Güvence Yaklaşımı Üzerine Kavramsal Bir İnceleme. Muhasebe Bilim Dünyası Dergisi, 20(2), 347 374.

Kartal, M. T., \& Çoban Çelikdemir, N. (2019a). Bankalarda İç Kontrol ve İç Denetim Faaliyetlerinin Eşgüdümü: Şube Denetim Faaliyetleri Üzerine Bir İnceleme. TíDE Academia Research, $1(1), 33-53$.

Kartal, M. T., \& Çoban Çelikdemir, N. (2019b). Türk Bankacıllk Sektöründe İç Denetim Bölümlerinin Organizasyonel Konumu: Ulusal ve Uluslararası Düzenlemeler Çerçevesinde Karşılaştırmalı Bir İnceleme. Mali Çözüm, 156, 89-115.

Lenghel, R. D., \& Miculescu, M. N. (2016). Current Requirements in Communicating Findings of Statutory Audit to Individuals in Governance Entity. Quaestus, (9), 298-304.

Libby, R. (1979). Bankers' and Auditors' Perceptions of the Message Communicated by the Audit Report. Journal of Accounting Research, 99-122.

Noyan, E. (2002). Bankalar Hukuku. Nadir Kitap.

Özbek, Ç. (2012). İç Denetim. TiDE Yayınları, Yayın No: 3.

TIDE. (2013). Çerçeve ve Ekler, İç Kontrol-Bütünleşik Çerçeve. TIDDE Yayınları, Yayın No: 11.

TIDE. (2017). Standartlar. https://tide.org.tr/file/documents/pdf/UMUC-2017-updated.pdf, Erişim Tarihi: 25.10.2019.

TiDE. (2019). İç Denetimin Tanımı, Uluslararası Mesleki Uygulama Çerçevesi, https://www.tide.org.tr/page/26/Ic-Denetimin-Tanimi, Erişim tarihi: 25.10.2019.

Tuanakota. M. T. (2009). Menghitung Kerugian Keuangan Negara dalam Tindak Pidana Korupsi. Penerbit Salemba Empat.

Yurtsever, G. (2009). Teftişten İç Denetime Banka Müfettişliği. TBB Yayını.

Yüksel, S., Zengin, S., \& Kartal, M. T. (2016). Banka Personelinin Teftiş Kuruluna Bakış Açısının Değerlendirilmesi. Finans Politik ve Ekonomik Yorumlar Dergisi, 53(622), 101-115.

Zhou, S., Simnett, R., \& Hoang, H. (2016). Combined Assurance as a New Assurance Approach: Is It Beneficial to Analysts? https://www.researchgate.net/publication/315029098_Combined_Assurance_as_a_New_A ssurance_Approach_Is_It_Beneficial_to_Analysts, Erişim Tarihi: 25.10.2019. 